\title{
What to do with faulty construction of public lighting?
}

\begin{abstract}
In the following paper we try to explain some of the legal rules concerning cases of defective implementation of public lighting. Public Lighting Construction Agreements concluded after 1st January 2014 are governed entirely by new Civil Code, including the rights of defective performance. The new regulation is based largely on the adjustment of the cancelled Commercial Code, so we focus only on significant changes and innovations in these matters introduced with effect from 1st January 2014 by the new Civil Code.
\end{abstract}

Keywords: Construction of public, a contract for work, new Civil Code, cancelled Commercial Code.

\section{Úvod}

V následujícím příspěvku se pokusíme přiblížit některá právní pravidla dopadající na prípady vadné realizace veřejného osvětlení. Poukážeme při tom rovněž na některé novinky, které $v$ těchto záležitostech zavedl s účinností od 1. 1. 2014 nový občanský zákoník.

\section{Povaha smlouvy o zhotovení veřejného osvětlení a relevantní právní úprava}

Výstavba veřejného osvětlení v praxi probíhá nejčastěji na základě smlouvy uzavírané mezi príslušnou obcí, popřípadě jiným subjektem zajišt'ujícím veřejné osvětlen [1], a příslušným dodavatelem (zpravidla podnikatelem). Taková smlouva je pak z právního hlediska obvykle považována za smlouvu o dílo, kterou v současnosti upravuje nový občanský zákoník [2] („NOZ“) a v minulosti upravoval dnes již zrušený zákoník obchodní [3] („Obchodní zákoník"). Základem takové smlouvy je povinnost zhotovitele řádně provést dílo (veřejné osvětlení) a povinnost objednatele (obce, kraje, popř. jiného subjektu) toto dílo převzít a zaplatit za něj sjednanou cenu.

$\checkmark$ některých prípadech však mưže nastat situace, kdy veřejné osvětlení zhotovované „na zakázku“ príslušným podnikatelem neodpovídá ve smlouvě předvídanému výsledku a je provedeno s vadami. To, jak mohou (musí) strany postupovat, by mělo v prvé radě vyplývat ze samotné smlouvy o dílo. Neobsahuje-li však taková smlouva zvláštní úpravu, uplatní se podpưrný zákonný režim. Jak bylo v úvodu tohoto príspěvku zmíněno, došlo s účinností od 1. 1. 2014 k změně právní úpravy, když předmětné smlouvy o dílo již neupravuje Obchodní zákoník, ale NOZ.

I v současnosti však může najít zrušený Obchodní zákoník při řešení sporů z vadného provedení veřejného osvětlení uplatnění, a to $v$ př́padech smluv uzavřených před 1. 1. 2014. Podle zákona totiž platí, že práva a povinnosti vzniklé z porušení smluv uzavřených přede dnem účinnosti NOZ, se rrídí předpisy účinnými do 31. 12. 2013 (tedy včetně Obchodního zákoníku). [4]

\section{Řešení vad dle Obchodního zákoníku}

Dílo (zhotovované veřejné osvětlení) má vady, jestliže neodpovídá výsledku určenému ve smlouvě. [5] $V$ prvé řadě tedy rozhoduje popis zamýšlených vlastností díla ve smlouvě. To ovšem neplatí bez výhrady. V některých prípadech je třeba respektovat závazná pravidla 0 jakostních a technických podmínkách pro provádění konkrétního díla. [6] To se týká především některých českých technických norem, jejichž dodržování je vyžadováno zákonem nebo vyhláškou. [7] Je-li pak zhotovení veřejného osvětlení $v$ rozporu s takovými normami, je namístě konstatovat, že dílo má vady a objednateli v důsledku toho vznikají příslušná oprávnění.
Vedle toho může sama smlouva odkázat v popisu kvality prováděného díla na technické normy, které se tak stanou pro strany závazné, byt' by jejich dodržování nebylo v daném prípadě vyžadováno zákonem ani příslušnými prováděcími předpisy.

Další otázkou, kterou je třeba $v$ souvislosti s existencí vad řešit, je okamžik jejich vzniku. Na tom, kdy vady vznikly, totiž závisí vůbec vznik odpovědnosti zhotovitele za vadné plnění a tomu odpovídajících práv na straně objednatele. Existují-li vady k okamžiku předání díla nebo k okamžiku přechodu nebezpečí škody zhotovované věci (přechází-li např. podle dohody stran později), pak vzniká odpovědnost zhotovitele bez dalšího. Vznikne-li vada později, odpovídá za ni zhotovitel jen, pokud byla sjednána záruka za jakost nebo, byla-li způsobena porušením jeho povinností. [8] Vznik vady však nelze zaměňovat $s$ prípadem, kdy vada byla po předání pouze zjištěna, tj. stala se zjevnou. I taková vada mohla existovat již prí předání díla, byt' by se jednalo o vadu skrytou.

To, zda bylo dílo předáno s vadami nebo ne, je podle Obchodního zákoníku naprosto zásadní pro vznik práva zhotovitele na zaplacení ceny za dílo. Platí to pro prípady, kdy ve smlouvě není zvláštních pravidel pro splatnost ceny za dílo. Obchodní zákoník totiž stanoví podpưrné pravidlo, dle kterého právo na zaplacení ceny za dílo vzniká provedením díla. Provedením díla se pak rozumí jeho řádné ukončení, to je ukončení bez vad, a jeho předání. [9] Není-li tedy vznik povinnosti objednatele zaplatit cenu za dílo ve smlouvě vázán například na pouhé předání díla, nemá zhotovitel dle Obchodního zákoníku právo na zaplacení ceny díla, předá-li dílo s vadami (byt' skrytými).

V návaznosti na předání díla je zákonem konstruována důležitá povinnost objednatele. Ten totiž musí podle možností co nejdřive po předání dílo prohlédnout nebo jeho prohlídku zařídit. [10] Neučiní-li to, může následně přijít o možnost uplatňovat svá práva $z$ vadného plnění. Zákon totiž stanoví lhůty, ve kterých musí objednatel vady reklamovat. V prípadě, že vady zjistí, musí je vždy reklamovat bez zbytečném odkladu po tomto zjištění. Pokud se jedná o vady, které měly být zjištěny při řádně provedené prohlídce (byt' provedena $v$ daném prípadě nebyla), musí je reklamovat bez zbytečného odkladu poté, kdy měl objednatel prohlídku provést. Jde-li o vady, které mohly být zjištěny teprve později (byt' by je objednatel nezjistil), musí je objednatel reklamovat bez zbytečného odkladu poté, co je měl zjistit. $V$ př́padě veřejného osvětlení však nejpozději do pěti let od předání díla (veřejné osvětlení Ize zpravidla považovat za stavbu, proto se neuplatní Ihůta dvou, ale pěti let). Je-li sjednána záruka, uplatní se místo této doby záruční doba. [11]

Dojde-li ke zjištění vad později než ve výše uvedených Ihůtách (a nestanoví-li sama smlouva něco jiného), může to 
zhotovitel $v$ prípadném soudním rízení namítnout, $\mathrm{v}$ důsledku čehož soud objednateli žádná práva $z$ vadného plnění nepřizná. To neplatí, jestliže se jednalo o vady, které jsou důsledkem skutečností, o nichž zhotovitel věděl nebo musel vědět $v$ době předání díla. [12]

Nedojde-li ve výše naznačeném smyslu k zániku nároků $z$ vadného plnění, může se objednatel ze zákona domáhat odstranění vad díla nebo slevy z ceny za dílo. Jednalo-li se však o takové vady, v důsledku kterých byla smlouva porušena podstatným způsobem, může též uplatnit právo na odstoupení od smlouvy, čímž smlouva zanikne. [13]

Pokud však dojde k odstoupení od smlouvy o dílo, jehož předmětem je zhotovení veřejného osvětlení, v důsledku jeho vadného provedení, musí se strany vypořádat v intencích přislušných zákonných ustanovení. Pro takové prípady se uplatní pravidlo, dle kterého bude muset objednatel zhotoviteli uhradit to, oč se zhotovováním veřejného osvětlení obohatil. [14] Objednatel tak zejména musí vždy pečlivě zvažovat, zda odstoupení od smlouvy bude mít pro něj žádoucí právní účinky. Pokud by se totiž jednalo o situaci, kdy se zhotovitel zavázal zhotovit veřejné osvětlení v cenně nižší než obvyklé, mohl by objednatel $v$ důsledku odstoupení od smlouvy nakonec zaplatit více, než kolik činila původně sjednaná cena ve smlouvě. [15]

Kromě již uvedených nároků je třeba rovněž upozornit na vznik povinnosti zhotovitele nahradit prípadnou škodu, která $v$ důsledku vadného provedení veřejného osvětlení vznikne na straně objednatele. $V$ daném prípadě se může jednat například o škodu, jejíž náhradu uplatnili vůči objednateli třetí osoby $v$ důsledku nefunkčního veřejného osvětlení, resp. porušení povinnosti péče o pozemní komunikace.

Při uplatňování práv $z$ vadného plnění je třeba pamatovat rovněž na běh promlčecích Ihůt, při jejichž zmeškání může objednatel v případném soudním řízení ztratit své nároky, namítne-li promlčení protistrana. Řídí-li se daný vztah Obchodním zákoníkem, je promlčecí doba čtyřletá a počíná běžet od předání díla nebo od okamžiku, kdy dílo měl převzít objednatel a v rozporu se svou povinností tak neučinil. [16] Jde-li o vady, na které se vztahuje záruční doba, počíná čtyřletá promlčecí doba běžet ode dne včasné reklamace vady $v$ průběhu záruční doby. [17]

\section{Řídí-li se smlouva NOZ}

Jak bylo uvedeno, smlouvy o zhotovení veřejného osvětlení uzavřené po 1. 1. 2014 se již zcela řídí NOZ, včetně práv z vadného plnění. Nová úprava vychází do značné míry z úpravy zrušeného Obchodního zákoníku, proto bychom se $v$ následujících rádcích zaměřili pouze na některé významné změny, které NOZ přináší, přičemž v ostatním Ize $v$ zásadě odkázat na to, co bylo výše napsáno $\mathrm{k}$ aspektům úpravy Obchodního zákoníku.

Stejně jako $v$ prípadě Obchodního zákoníku stanoví NOZ dispozitivní pravidlo, že zhotovitelovo právo na zaplacení ceny díla vzniká provedením díla. [18] Jiným způsobem jsou však definovány jednotlivé kroky, ze kterých se provedení díla skládá. Dílo je provedeno, je-li rádně dokončeno a předáno. Dokončením se však již nerozumí zhotovení díla bez jakýchkoliv, byt' drobných vad, ale okamžik, kdy zhotovitel předvede jeho způsobilost sloužit svému účelu. [19] Bližší úpravu postupu předvedení způsobilosti díla by měla obsahovat smlouva. Smlouva by mohla stanovit napríklad závazná kritéria týkající se světelně technických parametrů, které je zhotovitel povinen demonstrovat, apod. Pokud má i po takovém dokončení a předání dílo vady, je třeba ze strany objednatele nastalou situaci řešit uplatněním práv z vadného plnění. Tyto vady však samy o sobě neznamenají, že zhotoviteli nevznikne právo na zaplacení ceny díla. Pokud by tomu tak mělo být, musela by to smlouva výslovně stanovit.

Z hlediska samotného předání díla je podstatné, zda jej objednatel převzal s výhradami, nebo bez výhrad. Pokud totiž objednatel převzal dílo bez výhrad, platí, že mu soud nepřizná právo ze zjevné vady díla, namítne-li zhotovitel, že právo nebylo uplatněno včas. [20]

NOZ obsahuje nově několik speciálních ustanovení pro prípad, kdy se jedná o smlouvu o dílo, jehož předmětem je stavba. Ta se uplatní i ve vztahu k veřejnému osvětlení, jež je pravidelně stavbou. Důležité je zejména pravidlo, podle kterého objednatel nemá právo odmítnout převzetí stavby pro ojedinělé drobné vady, které samy o sobě ani ve spojení s jinými nebrání užívání stavby funkčně nebo dokonce esteticky, ani její užívání podstatným způsobem neomezují. [21] Chtějí-li strany podrobit smlouvu prísnějšímu režimu, mohou toto ustanovení smluvně vyloučit.

Zásadní novinkou, kterou NOZ ve vztahu ke smlouvě o dílo, jehož předmětem je stavba, přináší, je rozšíření odpovědnosti za vady kromě zhotovitele i na další osoby. Platí, že $v$ případě, že bylo plněno vadně, může se objednatel se svými nároky z vadného plnění obracet nejen na zhotovitele, ale také na i) subdodavatele zhotovitele, ii) na toho, kdo dodal stavební dokumentaci, a iii) na toho, kdo prováděl stavební dozor. Všechny tyto osoby jsou zavázány společně a nerozdílně se zhotovitelem, což znamená, že objednatel se může obrátit s celým svým nárokem na kteroukoliv z nich. [22]

Změnu přinesl NOZ také v úpravě promlčení. Nově se uplatní nikoliv čtyřletá, ale trríletá promlčecí doba, která ve vztahu $k$ právům $z$ vadného plnění počne běžet ode dne, kdy byly $v$ souladu se zákonem, resp. smlouvou, práva $z$ vadného plnění uplatněna u zhotovitele. [23]

\section{REFERENCES}

[1] Srov. SEQUENS, Tomáš, Petra NOVÁKOVÁ, Richard HAMRAN: Veřejné osvětlení a obec pod lupou zákona, který pojednává o subjektech, které jsou povinny zajišt'ovat veřejné osvětlení osvětlující pozemní komunikace.

[2] Tj. zákonem č. 89/2012 Sb., občanským zákoníkem v platném znění.

[3] Tj. zákon č. 531/1991 Sb., obchodní zákoník, ve znění pozdějších předpisů.

[4] Viz ustanovení § 3028 odst. 3 NOZ, dle kterého: „Není-li dále stanoveno jinak, rídí se jiné právní poměry vzniklé přede dnem nabytí účinnosti tohoto zákona, jakož i práva a povinnosti z nich vzniklé, včetně práv a povinností z porušení smluv uzavřených přede dnem nabytí účinnosti tohoto zákona, dosavadními právními předpisy. To nebrání ujednání stran, že se tato jejich práva a povinnosti budou rídit tímto zákonem ode dne nabytí jeho účinnosti. “"

[5] Viz ustanovení § 560 odst. 1 Obchodního zákoníku, dle kterého „Dílo má vady, jestliže provedení díla neodpovídá výsledku určenému ve smlouvě."

[6] Srov. POKORNÁ, Jarmila: Obchodní zákoník: komentár. Vyd. 1. Praha: Wolters Kluwer Česká republika, 2009, xxxv, 1079 s. Komentáŕe Wolters Kluwer. 
[7] Např. normy ČSN 13201 - 1 až 4 Osvětlení pozemních komunikací vydané ÚNMZ. K podrobnějšímu rozboru problematiky závaznosti technických norem ve veřejném osvětlení srov. SEQUENS, Tomáš, Petra NOVÁKOVÁ, Richard HAMRAN. Normy ve veřejném osvětlení z pohledu práva.

[8] Viz ustanovení § 560 odst. 2 Obchodního zákoníku, dle kterého: „Zhotovitel odpovídá za vady, jež má dílo v době jeho předání; jestliže však nebezpečí škody na zhotovené věci přechází na objednatele později, je rozhodující doba tohoto prechodu. Za vady díla, na něž se vztahuje záruka za jakost, odpovídá zhotovitel $v$ rozsahu této záruky." a § 560 odst. 3 Obchodního zákoníku, dle kterého: „Zhotovitel odpovídá za vady díla vzniklé po době uvedené v odstavci 2 , jestliže byly zpưsobeny porušením jeho povinností."

[9] Viz ustanovení § 554 odst. 1 Obchodního zákoníku, dle kterého: „Zhotovitel splní svou povinnost provést dílo jeho raádným ukončením a předáním předmětu díla objednateli v dohodnutém místě, jinak v místě stanoveném tímto zákonem." a rozsudek Nejvyššího soudu sp. zn. 32 Odo 1326/2006, ze dne 13. 11. 2008: „Mělo-li tedy predané dílo nedodělky, je zřejmé, že žalobkyně, jako zhotovitelka, nesplnila svou povinnost provést dílo jeho řádným ukončením a predáním. Dílo, které je vadné a má nedodělky, nelze totiž ve smyslu § 554 odst. 1 obch. zák. považovat za dílo provedené, a to ani tehdy, když je jako je tomu v posuzovaném prípadě objednatel prevezme. Pokud mezi účastníky nebylo sjednáno jinak, zhotoviteli v takovém prípadě právo na zaplacení ceny díla nevznikne."

[10] Viz ustanovení § 562 odst. 1 Obchodního zákoníku, dle kterého: ,je objednatel povinen předmět díla prohlédnout nebo zařídit jeho prohlídku podle možnosti co nejdřive po předáni předmětu díla."

[11] Viz ustanovení § 562 odst. 2 Obchodního zákoníku, dle kterého: „Soud neprizná objednateli právo $z$ vad díla, jestliže objednatel neoznámí vady díla a) bez zbytečného odkladu poté, kdy je zjistí, b) bez zbytečného odkladu poté, kdy je měl zjistit při vynaložení odborné péče pri prohlídce uskutečněné podle odstavce 1, c) bez zbytečného odkladu poté, kdy mohly být zjištěny později při vynaložení odborné péče, nejpozději však do dvou let a u staveb do pěti let od predání predmětu díla. U vad, na něž se vztahuje záruka, platí místo této Ihůty záruční doba."

[12] Viz ustanovení § 562 odst. 3 Obchodního zákoníku ve spojení s ustanovením § 428 odst. 2 a 3 Obchodního zákoníku.

[13] Viz ustanovení § 564 ve spojení s ustanoveními § 436 až 441 Obchodního zákoníku.

[14]Viz ustanovení § 544 odst. 1 Obchodního zákoníku, dle kterého: „Má-li ke zhotovované věci vlastnické právo objednatel a věc nelze vzhledem $k$ její povaze vrátit nebo předat zhotoviteli, je objednatel povinen uhradit zhotoviteli to, o co se objednatel zhotovováním věci obohatil, jestliže závazek zanikl z důvodu, za který objednatel neodpovídá."
[15]Srov. CHALUPA, Luboš: Vypořádání po odstoupení od smlouvy o dílo. Právní rádce [online]. 2004 [cit. 2014-08-05]. Dostupné z: http://pravniradce.ihned.cz/c1-13873890vyporadani-po-odstoupeni-od-smlouvy-o-dilo

[16] Viz ustanovení § 393 odst. 2 Obchodního zákoníku, dle kterého: „U práv $z$ vad věcí běží promlčecí doba ode dne jejich předání oprávněnému nebo osobě jím určené nebo ode dne, kdy byla porušena povinnost věc převzít. "

[17] Srov. rozsudek Nejvyššího soudu sp. zn. 32 Odo 1616/2005, ze dne 26. 9. 2007: „v prípadě nároků ze záruky za jakost se aplikuje speciální ustanovení § 393 odst. 2 ObchZ, podle něhož u nároků ze záruky za jakost běží promlčecí doba vždy ode dne včasného oznámení vady během záruční doby a u nárokủ z právních vad od uplatnění práva třetí osobou."

[18] Viz ustanovení § 2610 odst. 1 NOZ, dle kterého: „Právo na zaplacení ceny díla vzniká provedením díla."

[19] Viz ustanovení § 2605 odst. 1 NOZ, dle kterého: „Dílo je dokončeno, je-li předvedena jeho způsobilost sloužit svému účelu. “

[20]Viz ustanovení § 2605 odst. 2 NOZ, dle kterého „Převezme-li objednatel dílo bez výhrad, neprizná mu soud právo ze zjevné vady díla, namítne-li zhotovitel, že právo nebylo uplatněno včas."

[21] Viz ustanovení § $2628 \mathrm{NOZ}$, dle kterého „Objednatel nemá právo odmítnout prevzetí stavby pro ojedinělé drobné vady, které samy o sobě ani ve spojení s jinými nebrání uživání stavby funkčně nebo esteticky, ani její uživání podstatným způsobem neomezuji.."

[22] Viz ustanovení § 2630 odst. 1 NOZ, dle kterého: „Bylo-li plněno vadně, je vzhledem $k$ tomu, co sám dodal, zavázán se zhotovitelem společně a nerozdílně a) poddodavatel zhotovitele, ledaže prokáže, že vadu způsobilo jen rozhodnutí zhotovitele nebo toho, kdo nad stavbou vykonával dozor, b) kdo dodal stavební dokumentaci, ledaže prokáže, že vadu nezpůsobila chyba ve stavební dokumentaci, a kdo prováděl dozor nad stavbou, ledaže prokáže, že vadu stavby nezpůsobilo selhání dozoru. “

[23] Srov. LAVICKÝ, Petr. Občanský zákoník: komentář. 1. vyd. V Praze: C.H. Beck, 2014, xx, s. 2217. Velké komentáře.

Authors: JUDr. Petra Nováková, Ph.D., Kocián Šolc Balaštík, advokátní kancelár, s.r.o., Czech Republic, www.ksb.cz, pnovakova@ksb.cz,

Mgr. Ondřej Mikula, Kocián Šolc Balaštík, advokátní kancelár, s.r.o., Czech Republic,www.ksb.cz, omikula@ksb.cz, JUDr. Tomás Sequens, Kocián Šolc Balaštík, advokátní kancelár, s.r.o., Czech Republic,www.ksb.cz, tsequens@ksb.cz 